\title{
AN ASSESSMENT OF RETENTION TREES IN HYLOCOMIOSA FOREST TYPE IN SOUTHERN LATVIA
}

Inga STRAUPE, Department of Silviculture, Forest Faculty, Latvia University of Agriculture Address: Akademijas iela 11, Jelgava, LV-3001, Latvia, inga.straupe@1lu.lv

Līga LIEPA, Department of Silviculture, Forest Faculty, Latvia University of Agriculture Address: Akademijas iela 11, Jelgava, LV3001, Latvia liga.liepa@outlook.com (corresponding author)

In Latvia the forest legislation requires that at least five living trees must be retained per hectare after clear-cutting. It is known that retention trees significantly increase the biodiversity in production forest landscape. After clear-cutting retention trees function as habitats for various lichens, mosses, insects, fungi and birds. Over time retention trees are incorporated into the young forests stand and provide presence of old trees, which is necessary for many endangered and rare species. After the death, these trees turn into coarse woody debris which is an essential habitat and feeding source for many taxa. However, the conservation and mortality of the retention trees has not been studied extensively because this approach has been established recently. The aim of this study was to evaluate development of the retention trees in Hylocomiosa type of forests in Southern Latvia. In total 12 young forest stands were surveyed in 2009 and 2015. The total area -13.7 ha, on average forest stand size varies from 0.5 to 3.0 ha. All the studied sites were harvested in 2002, 2004, 2006 and 2008. All measurements of tree species, height, and diameter and defoliation class assessed and the status of tree (growing tree, coarse woody debris - snags, stems and downed logs) was indicated. Results show that after the studied period of seven years 24 retention trees died. Average level of the tree mortality is $15 \%$. The mortality level of Scots pine retention trees is $5.8 \%$, for aspen $-50 \%$ and that for birch $-92.3 \%$. An average it is 8.5 green retention trees per 1 ha of young stand $\left(22.9 \mathrm{~m}^{3} \mathrm{ha}^{-1}\right)$. On average 2.3 pieces coarse woody debris are per 1 ha of young stand $\left(3.52 \mathrm{~m}^{3} \mathrm{ha}^{-1}\right)$, mostly - aspen wood $\left(2.4 \mathrm{~m}^{3} \mathrm{ha}^{-1}\right)$. Woody debris of the young stands is divided to the first 4 decay levels according to classification (Stokland et al., 2001). $50 \%$ of the listed woody debris is related to the $3^{\text {rd }}$ decay level which means that woody debris is moderately decomposed.

Keywords: Biodiversity concern, clear-cutting, hemiboreal forests, species diversity, retention trees, tree mortality

\section{INTRODUCTION}

The biodiversity conservation challenge has been influenced by human activity in recent past wheras land use and land cover changes has been detected (Angelstam et al., 2017). In Europe, the forest areas for conservation have been closely related to naturalness wheras composition, structure and functions are valuable factors. However, the most common approach to preserve nature values are to set aside, for example, national parks, nature reserves, microreserves etc. However, the conservation of large-scale territories is fragmented and production forest areas are outside of this network. This approach provides habitat fragmentation, loss of connectivity and isolation between territorries. According to sustainable forest management principles also nature conservation aspects in production forests have to be taken into account.

It is known, that since Convention of Biological Diversity in 1992, the nature conservation, especially in forest ecosystems, has become as a core topic and has attracted attention globally. In Baltic forests the main focus has been on the influence after intensive forest management activities and habitat preservation in fragmented forest landscape. To implement the current condition in these forests, the various conservation tools for preservation of species and habitats in production forests has been practiced. For instance, the preservation of EU habitat types, green-tree retention approach, establish of microreserves for protected species and habitats and others.

The past decade the concept of green retention trees after final harvesting were applied in boreal and temperate forest ecosystems (Angelstam and Pettersson, 1997). It is known, that in Baltic forests clear-cutting is most common approach for final harvest in production forests and therefore green retention tree approach is mandatory. This concept functioning as habitats for wildlife during the stand replacement phase, increasing structural diversity in regenerated stand and providing connectivity in forested landscape (Lindenmayer and Franklin, 1997). Green retention trees also help to sustain populations of saproxylic insect communities and adapt to the large scale disturbances. Also biodiversity benefits of retained trees have been studied on several red-listed species especially on bryophyes and lichens (Lõhmus et al. 2006), understorey vegetation, fungi and others. The core elements for these groups are substrate availability for many taxa 
therefore many studies has been focused on tree species diversity and dynamics due to certain time period. Thus, species living on substrate, for instance, epiphytes and insects has been directly dependent on retained trees. In various Northern hemisphere studies it has been summarized that green retention trees populated with epiphytic communities may functioning as hotspots of their recolonization for next forest generations (Sillet and McCune 1998; Sillet et al. 2000). Also inderect effects of retained trees on many taxa, for instance, birds, mammals, reptiles have been studied regarding to habitat preferences. However, the species diversity and efficenty of functiong retained trees in forest landscapes have been commonly studied in many countries to detect the efficiency of this conservation concept.

However, concern about the apperance of sensitive forest-dwelling species after massive forest harvesting have developed new concervation tools where biodiversity conservation approaches has to be taken into account such as green retention trees. Therefore studies oriented on substrate availability are essential to predict the dynamics of species diversity and changes. This study may be the first in Latvian forests where the dynamics of retained trees as substrate availability for taxa has been studied. Also retained trees are exposed by natural disturbances wheras wind and fire are main agents which are creating downed woody debris and, lesser degree, standing dead wood. The retained trees may constitute habitats for species already present during early stages after succession and these tree patches can provide range of important structural features in the developing stand, including diversity of dead wood substrate. The long-term effects have to be studied in retained tree patches to predict the presence of large-diameter dead wood that otherwise would be missing in regenerated stands. There is a lack of studies in which long-term dynamics of green retention trees on structural biodiversity in general has been studied. In this study we focused on 7 year dynamics of forest structural features in retained tree patches. The aim of the study was to estimate the differences after 7 years on forest structural features in retained tree patches in managed forest landscape.

\section{MATERIALS AND METHODS}

This study was carried out in Southern part of Latvia located at $57^{\circ} \mathrm{N}$ and $23^{\circ} \mathrm{E}$ (Figure 1). Latvia falls into hemiboreal vegetation zone (Ahti et al, 1968) where forests cover approx. 54\% of the country. The mean air temperature in January is $5^{\circ} \mathrm{C}$ and July $+17^{\circ} \mathrm{C}$ and annual precipitation is approximately $600 \mathrm{~mm}$ (Kārklinšs et al, 2009). In total 12 study sites were chosen for analysis. All studied sites were established in Hylocomiosa forest type and chosen stands had been harvested in 2002, 2004, 2006 and 2008. Study sites representing three sample plots per each harvested year.

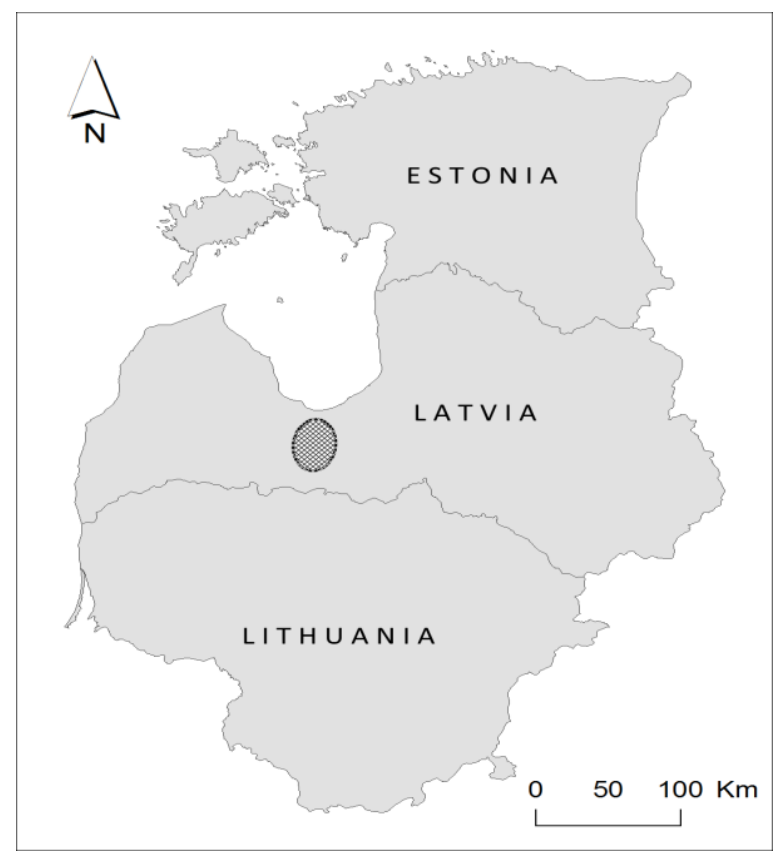

Figure 1. The location of studied area.

Latvian forest legislation require at least 5 green retention trees per clear-cut hectare. Also if prefered tree species such as oak, linden, pine, elm, aspen, black alder and aspen are present. It is required to include bird nests if diameter is $\geq 50$ $\mathrm{cm}$ and it's tree line or patch buffer and also trees with cavities larger than $10 \mathrm{~cm}$ diameter (MK noteikumi Nr. 935, 2012).

The study included all 12 sites that have been harvested during the 2002-2008. During the vegetation season of 2009 and 2016 all live trees were mapped including their diameter at breast height ( $\mathrm{DBH} \geq 10 \mathrm{~cm})$, height, species, tree crown defoliation and visual damages. In addition, for green retention trees the visual damages after harvesting, woodpecker holes, polyphore fruiting bodies and insect signs in wood were determined. For dead wood also decay stage according to Siitonen et al. (2001) were determined, for standing dead wood DBH and height were measured, and for downed logs diameter at intersection point $(\geq 10 \mathrm{~cm})$ and also lenght of the log or piece was measured. 
The volume of trunk for each living and standing dead tree was calculated using a species specific formula (Liepa, 1996). The volume of downed logs and their pieces was calculated by Liepa (1996) formula. Significan treatment effects between time scale and studied sites were compared using T-test.

\section{RESULTS}

Species richness and mortality. The purpose of the study was to analyze retained tree dynamics after 7 years. The data were acquired from retained tree patches in production forests placed in stands where final harvesting was made within different years. In 2009 studied sites showed that mortality of retained trees is $11 \%$, but after 7 years it increased up to $30 \%$. In young forest stands aged of 8-10 years the mortality of green retention trees is higher than in stands aged of 12-14 years. It is related with higher precentage of deciduous tree species where these species are more sensitive to abiotic changes. For example, in 2009 the average number of green retention trees is 9.8 per ha, but in $2016-8.5$ trees per ha. The average volume of green retention trees in 2009 is $23.4 \mathrm{~m}^{3} \mathrm{ha}^{-1}$, but in $2016-22.9 \mathrm{~m}^{3} \mathrm{ha}^{-1}$.

In all studied sites the majority of tree species consists of Scots pine (Pinus sylvestris), for example, $90.7 \%$ from the total number of green retention trees, where the mortality is up to 5.8\%. Mean while the mortality of deciduous species, for example, birch (Betula pendula) reach up to $92.3 \%$ and that for aspen (Populus tremula) 50\%. However, in most cases standing dead wood features are deciduous trees. In fewer cases black alders (Alnus glutinosa) were retained, we found only 2 trees in all studied sites. Also it is known that black alders are resistant species against abiotic changes (www.lvm.lv). In total we found only one tree of Norway spruce (Picea abies) and according to species biological characteristics, these species provides high rate of mortality, which is caused by wind damages.

In summary, the mortality of green retention trees are strongly influenced by changes in abiotic factors and damages from wind and fire are the most common. We found that mortality of retention trees is higher in young forest stands where adjacent stands were harvested. Also the lower mortality of retention trees has been observed in sites with tree patches or in sites where the distance to adjacent stand is closer.

The diversity of dead wood. In young forest stands in 2009 the average volume of dead wood was $2.5 \mathrm{~m}^{3} \mathrm{ha}^{-1}$, but in $2016-3.5 \mathrm{~m}^{3} \mathrm{ha}^{-1}$. The higher density of standing dead wood has been observed in young forest stands with age of 8-10 years where the density of them in 2009 was 0.3 snags per ha (average volume $1.1 \mathrm{~m}^{3} \mathrm{ha}^{-1}$ ), but in $2016-1.0 \mathrm{snags}$ per ha (average volume $2.3 \mathrm{~m}^{3} \mathrm{ha}^{-1}$ ). On average the mortality of retention trees in 2009 was $11 \%$, but in $2016-15 \%$. The large part of retention trees (approx. 85\%) is still green and healthy condition. The studies about condition and dynamics of retention trees in Latvian state forest areas showed that since this concept has been created the mortality of all retained trees reached up to $43 \%$ (ww.lvm.lv).

In all studied sites approximately $50 \%$ consist of downed dead wood and it is related to $3^{\text {rd }}$ decay stage where bark has been partly peeled off and wood is moderately decayed. This study showed that between 2009 and 2016 diversity of the dead wood has increased. It is a positive trend, which provides substrate availability for species where moderate and late decay stages are essential. Therefore the diversity of downed dead wood in different decay stages in young forest stands increase the ecological value of forests.

\section{CONCLUSIONS}

1. In young forest stands on average there are 8.5 trees per 1 ha and their average volume is $22.9 \mathrm{~m}^{3} \mathrm{ha}^{-1}$.

2. During the period of 7 years the mortality of retention trees reached up to $15 \%$.

3. The mortality of retention trees is correlated with tree species where higher mortality rate is for birch species $-92 \%$, that for aspen $-50 \%$ and that for Scots pine $-6 \%$.

4. The average defoliation rate of green retention trees in studied young stands is $13 \%$.

5. In young forest stands there are 2.3 downed dead wood pieces and 0.5 standing dead wood items per ha, which is 4.6 $\mathrm{m}^{3} \mathrm{ha}^{-1}$. The majority of dead wood consists of aspen (Populus tremula) $-3.2 \mathrm{~m}^{3} \mathrm{ha}^{-1}$.

6. The diversity of downed dead wood pieces related to $3^{\text {rd }}$ decay stage $(50 \%), 2^{\text {nd }}$ decay stage $-22 \%$ and that for $1^{\text {st }}-$ $14 \%$ and for $4^{\text {th }}-14 \%$.

7. In different age of young forest stands the dynamics of retention trees is not statistical significant where the majority of retained trees (on average $85 \%$ ) is in healthy condition.

\section{ACKNOWLEDGEMENTS}

We are grateful to E. Krētaine and I. Loginova for help with a fieldwork.

\section{REFERENCES}

1. Ahti, T., Hämet-Ahti, L., Jalas, J. 1968. Vegetation zones and their sections in North- Western Europe. Annales Botanici Fennici, Vol. 5, pp. 169-211.

2. Angelstam, P., Pettersson, B. 1997. Principles of present Swedish forest biodiversity management. Ecological Bulletins, pp.191203.

3. Angelstam, P., Khaulyak, O., Yamelynets, T., Mozgeris, G., Naumov, V., Chmielewski, T.J., Elbakidze, M., Manton, M., Prots, B., Valasiuk, S., 2017. Green infrastructure development at European Union's eastern border: Effects of road infrastructure and forest habitat loss. Journal of Environmental Management, Vol. 193, pp. 300-311. https://doi.org/10.1016/j.jenvman.2017.02.017 
4. JSC Latvian State Forest, 2016, available at http://www.lvm.lv/

5. Liepa, I. 1996. Pieauguma mācība, LLU, Jelgava. [In Latvian]

6. Lindenmayer, D.B. and Franklin, J.F., 1997. Forest structure and sustainable temperate forestry: a case study from Australia. Conservation Biology, Vol. 11, pp. 1053-1068. https://doi.org/10.1046/j.1523-1739.1997.96150.x

7. Lõhmus, P., Rosenvald, R. and Lõhmus, A., 2006. Effectiveness of solitary retention trees for conserving epiphytes: differential short-term responses of bryophytes and lichens. Canadian Journal of Forest Research, Vol. 36, Iss. 5, pp. 1319-1330. https://doi.org/10.1139/x06-032

8. MK noteikumi N.R. 935 Noteikumi par koku ciršanu mežā. 2012. Available at https://likumi.lv/doc.php?id=253760 [In Latvian]

9. Siitonen, J., 2001. Forest management, coarse woody debris and saproxylic organisms: Fennoscandian boreal forests as an example. Ecological Bulletins, pp.11-41.

10. Sillet, S.C., and McCune, B., 1998. Survival and growth of cyanolichen transplants in Douglas-fir forest canopies. Bryologist, Vol. 101, pp. 20-31. https://doi.org/10.1639/0007-2745(1998)101[20:SAGOCT]2.0.CO;2

11. Sillet, S.c., McCune, B., Peck, J.E., and Rambo, T.R., 2000. Four years of epiphyte colonization in Douglas-fir forest canopies. Bryologist, Vol. 103, pp. 661-669. https://doi.org/10.1639/0007-2745(2000)103[0661:FYOECI]2.0.CO;2 